\title{
CONSTITUTIONAL CHANGE, LEGISLATIVE PERFORMANCE AND INSTITUTIONAL CONSOLIDATION
}

\section{Argelina Cheibub Figueiredo and Fernando Limongi}

In this article we discuss the relations between the executive and legislative and the consequences of these relations on the structuring of the legislative power. The study covers the period that begins with the promulgation of the Constitution of 1988. We focus on one of the least studied dimensions of the Brazilian political system, namely, the relations between the executive and legislative as generators of legal norms.

The Constitution of 1988 approved two distinct and contradictory sets of measures. On one hand, the constitutional delegates approved a series of measures that tended to strengthen Congress, recovering powers taken away from the legislature during the military period. On the other hand, the Constitution upheld the legislative powers granted to the executive during the authoritarian period. The new Constitution has not annulled the prerogatives that allowed the executive to control the legislative process during the military regime.

* Published originally in Revista Brasileira de Ciências Sociais, n. 29, October 1995, pp. 175-200.

Translated by Frances Tornabene de Sousa and revised by Roderick Steel and the authors.
Therefore, there is an institutional continuity, little noted it must be said, between the authoritarian period and the present democratic one. As one would expect, this continuity affects legal output of the period studied. We show here that the executive branch, due to the legislative powers it possesses, commands the legislative process and in this way, undermines the strengthening of Congress as an autonomous power. The result is the atrophy of the legislative and the predominance of the executive, the main legislator de jure and de facto. ${ }^{1}$

Thus, the hypothesis that the legislature constitutes an obstacle to the action of the executive does not find support either by the analysis of the institutional framework or the legal output. The evidence points in the opposite direction: rather than being an obstacle, Congress facilitates the processing of presidential bills, and above all removes possible obstacles to presidential action.

The text is organized as follows. In the first part we discuss the institutional framework that regulates the functioning of the legislature and especially its relationship with the executive. The second and third parts contain an analysis of the legislative process and the legal output in the post- 
Constitution period: the second shows the predominance of the executive in the legislative process, focusing on the institutional advantages that explain this; the third explores the organizational characteristics of the House of Representatives, and its contribution to the establishment of the pattern observed in legislative-executive relations. The last part is a conclusion that summarizes the main points shown throughout this work and discusses the role of the legislature in the decisionmaking process. ${ }^{2}$

\section{The institutional framework}

With the enactment of the democratic Constitution of 1988, Congress recovered many of the powers taken away by the successive constitutional reforms imposed by the military governments. In several aspects, Congress had its powers broadened in relation to those established by the 1946 Constitution. The new Constitution allows Congress to contribute in an effective way to the formulation of public policies.

In this sense, Congress' most important conquest is the redefinition of its participation in the budgetary process and in the control of public finances. As is widely known, the military governments reduced the legislative role in this area to a minimum. Among the new attributes and prerogatives reserved for the legislature it is worth emphasizing the restoration of its ability to amend the budget, granting widerparticipation in the elaboration of the budget. It is also worth noting the strengthening of the Court of Accounts (Tribunal de Contas) and the greater participation of Congress in the nomination of this court's members.

Other measures, less far-reaching, also point to the strengthening of the legislative vis-à-vis the executive. For example: the quorum for overriding the presidential veto now depends on the vote of the absolute majority and no longer on two thirds of votes. Still in this chapter, the reach of the presidential veto itself was limited: the veto can no longer affect isolated words.

The strengthening of the legislative is also noticeable in the definition of areas that reserved for it the exclusive right to legislate. The most conspicuous case is found in the chapter referring to the approval of broadcasting and television concessions. The limitation of the executive's broad powers is found also in the Congress' ability to "stop the prescriptive acts of the executive which go beyond the regulatory power or the limits of legislative delegation" (Art. 49, V).

It is also worth noting that the members of the Constitutional Assembly paid attention to the institutional modernization necessary for the proper and efficient development of these new powers. The main measure adopted toward that end was of endowing the standing committees with the power to approve bills without referring them to the floor in pre-determined cases. This is the so-called "terminative power" of the committees. This means that the principle of the division of work built into the committee system was taken to its ultimate consequence: the committees are allowed to approve legislation without the floor's explicit manifestation. The constitutional delegates welcomed this innovation, seeing it as an incomparable institutional move toward the modernization of the legislature. They expected that this would lead to the redefinition of Congress' working practices. This institutional innovation would allow the unburdening of the legislative agenda. Therefore it was expected that the committees' terminative power would make Congress more effective and productive. $^{3}$

This is all well known and is emphatically underlined as much by the players involved in the process as by analysts. The new prerogatives mentioned above are presented as marks that allow the clear distinction between two moments: between the past authoritarian debasement of the legislature, on the one hand, and on the other, the present democratic affirmation of Congress' autonomy. Less noted however, is that many of the legislative powers obtained by the executive branch throughout the authoritarian period were not annulled by the 1988 Constitution. We now turn to the discussion of these points.

Even though redefined and granting less power to the president, the capacity to issue provisional decrees can be seen as the preservation of the presidential power to issue decree- 
laws. Article 58 of the 1967 Constitution granted the president the power to issue decree-laws in cases of "urgent or relevant public interest". According to the legal text, the decree-law came into effect on its publication and the deadline for Congress' deliberation on it was 60 days, at the end of which the project was automatically approved if Congress took no action. Hence the decree could be approved without the manifestation of Congress. Moreover, amendments could not be presented and the defeat of the decree did not invalidate its effect during the period it was in force.

Article 62 in the 1988 Constitution allows the president to issue a provisional decree with force of law. Congress must deliberate on it within 30 days. Contrary to what occurred with the decreelaw, a non-manifestation implies the loss of legal effect of the decree. If the provisional decree is rejected, Congress has the responsibility to regulate the relations resulting from the earlier application of the act, including the possibility of declaring the effects null from the time of issue. Another important difference resides in the fact that Congress can amend the decree issued by the president.

Although the differences are important and not devoid of practical effect, the existence of continuity between the decree-law and the provisional decree is undeniable. Above all because the executive branch does not depend on the legislature for its legislative acts to take effect. Undoubtedly, the provisional decree offers greater possibility for legislative intervention, whose action, however, will always be reactive. It is important to note that the reissuing of the provisional decree is not prohibited. Thus, non-approval is not equal to rejection. In practical terms, avoiding the quorum for the approval of provisional decrees and reissuing them before the expiration of their validity, the executive has an alternative way to maintain them in force without the approval of the legislature.

During the military regime, the president was granted the ability to unilaterally request the urgent processing procedure for his bills. More specifically: the president could define the deadline by which the legislature should decide on the issue submitted to it. If the legislature failed to deliberate within the stipulated deadline, the bill was automatically approved. Absent from the constitutional text of 1946, this prerogative was added to the list of presidential legislative powers in 1964 and was kept, with some alterations, in all the legal texts of the period. The 1988 Constitution grants the president the premgative of requesting urgency for the processing of legislative bills he sponsors, which means that if both the "Lower House and Federal Senate do not each manifest themselves successively regarding the bill, within at least forty-five days, it will be automatically included in the day's agenda, forbearing the deliberation of other bills in order to ensure a vote" (Art. 64, 2nd paragraph).

Once more, it can be seen that there is no absolute continuity. The authoritarian period's legislation established that Congress' silence implied the approval of the bill sent to it. The current Constitution forces Congress' manifestation, be it to reject or to approve. That is, it is not possible to block the processing of matters considered important by the president who can, in this manner, unilaterally dictate the legislative work agenda.

Even where the powers of the legislature were broadened, namely, in the area relative to budgetary and tributary issues, Congress' new powers cannot be overestimated. In the first place, it is worth noting that while the 1946 Constitution established that the executive and legislative branches share the initiative of these issues, the 1988 Constitution awards the monopoly of the initiative of these issues to the executive branch. The point is relevant because, as it refers to issues that must follow calendar requirements, it allows the executive to postpone the introduction of the bill in order to diminish the margin for maneuvering available to the legislature. ${ }^{4}$

Still in relation to this point, it is worth noting that all the laws establishing directives for the annual budget (LDO - leis de diretrizes orçamentárias) approved by Congress establish that, in case of non-compliance of the deadlines for deliberation of the budget, the executive branch is automatically authorized to spend up to 1/12th of the budget bill it is sent per month. ${ }^{5}$ Hence, the 
legislature foregoes its main bargaining power in the budget negotiation. The consequences of the non-approval of the budget are reduced to a minimum. In fact, through this mechanism, legislative participation in the elaboration of the budget decreases significantly.

As the example of the LDO shows, the analysis of the lines of continuity between the authoritarian period and the present one does not stop at the constitutional framework. In this aspect, it is interesting to note that the House's standing orders, elaborated after the Constitution's promulgation and justified by the need to tailor the internal organization of the legislature to the new constitutional framework, contributed little to altering the practices and habits that used to regulate the legislative work during the authoritarian regime. The legislative process is still run and controlled by a restricted number of congressional members, the college of leaders, to the detriment of the work of committees.

Running the risk of overstatement, we can say that this same pattern of functioning distinguished the Lower House throughout the authoritarian period. As is well known, the provisions of the "leadership vote", of the "closing of the question" and of "party loyalty", granted an eminent role to party leaders. As a consequence, the participation of the representatives in the decisionmaking process becomes practically unnecessary.

The work of the constitutional delegates ended up establishing an excessively centralized pattern of organization of legislative work. This is not the appropriate place to recount the complex and tortuous history of that process. ${ }^{6}$ It is sufficient to note that the reinterpretation of the National Constituent Assembly's internal rules that was victoriously supported by the Centrão (a coalition of center-right parties) created the opportunity for the occurrence of the so-called "black holes". ${ }^{7}$ This interpretation implied that the project offered by the representative in charge to give a report on the bill (the relator) was no longer taken as the status quo to which amendments could be offered. The above-mentioned black hole would then occur whenever no majority could be formed to support a matter to be included in the constitutional text. Besides this risk, the voting process became prohibitively long, given the number of amendments to be voted on as a separate matter. Hence the creation of a group that would prepare and coordinate the floor work. This group, basically formed by party leaders, was assigned the task of combining or selecting the amendments that would be voted on in the floor. That is, floor votes which were preceded by so-called leadership deals made in the aforesaid meetings between leaders. ${ }^{8}$

Although not foreseen by internal rules in force at the time, the meetings and leadership agreements have not lost their importance after the completion of the work of the constitutional delegates. To cite just one example, as he initiated the long process of approval of the new standing orders, the speaker, Paes de Andrade, explained that the criteria directing the voting process were established according to agreements made between the speaker and the party leaders. ${ }^{9}$

The House standing orders enacted in 1989 institutionalized the college of leaders ${ }^{10}$ composed by the speaker of the House and the majority, minority and other parties (or party coalitions) leaders. ${ }^{11}$ The act confers on the college of leaders the status of an auxiliary organ to the speaker in the main tasks relative to the organization of legislative works. Its more important task, along with the speaker, is to elaborate the agenda with the legislative proposals to be considered in the subsequent month. The speaker selects the day calendar according to this agenda.

The decisive role of party leaders does not depend exclusively on the college of leaders. The influence of the leaders on the setting of the agenda also depends on the weight given to their signatures on petitions, special requests, presentation of amendments, etc. In these cases the leader's manifestation is taken as the manifestation of his/ her party or coalition. ${ }^{12}$ The leaders therefore find themselves in a privileged position to influence the definition of legislative agenda.

The request for urgent processing of a bill is the most important way through which the college of leaders influences the legislative agenda. 
In accordance with article 151 of the standing orders, the procedure for processing a bill can be altered from ordinary to special in the cases "acknowledged through deliberation by the floor as being urgent". ${ }^{13}$ In practical terms, the approval of a request for urgency means that the issue to be discussed is discharged from the committee and included in the day calendar for floor deliberation.

There are two types of special procedure for processing bills that need to be distinguished: urgent and extremely urgent. While the first implies the inclusion in the following session, ${ }^{14}$ an extremely urgent procedure implies "automatic inclusion in the day calendar followed by immediate discussion and voting, even if the day's session is already underway". Article 55 of the standing orders establishes extremely urgent procedure to be applied to "relevant and non-deferrable matters of national interest".

Party leaders can present a request for urgency, the weight of their signatures depending on the number of representatives that they represent. ${ }^{15}$ In practice the urgency tends to be deliberated in the meetings of the college of leaders. ${ }^{16}$ The leaders submit the request to the floor and when they are in agreement, they obtain the approval of this through symbolic vote.

Thus there is an uncontestable control exercised by the college of leaders over the working agenda of the legislature. ${ }^{17}$ As we will see in detail in the following section, resorting to the urgent as well as extremely urgent procedures for processing bills is so frequent that the majority of approved matters tend to be processed in this way. Bills scheduled under urgent procedures are rarely rejected.

It should be noted now that the college of leaders, mutati mutantis, ends up taking the place of a leadership vote current during the authoritarian period. Of course, the institutional bases and the ways in which each of these provisions are used are very different. However, in both cases we note the preponderance of a small group of congressional members whose decisions are imposed on the rest. The consequence of this state of affairs is the devaluation of congressional activity itself.
Let us recapitulate the principal points raised throughout this section. The Constitution of 1988 establishes two apparently conflicting sets of rules. On the one hand, the legislature recovered many of the prerogatives it had during the previous democratic experience. However, on the other hand, the executive maintained a large part of the legislative powers it was endowed during the authoritarian period. With this, as we seek to demonstrate in the next sections, the executive can command the legislative process. The internal structure of the legislature parallels this preponderance. The functions that the college of leaders performs must be understood as the possible responses of a Congress immersed in this type of relation.

Having established the institutional framework under which legislative activity is developed, the following section discusses its consequences for legislative production and the role performed by the Congress in the Brazilian political system.

\section{The institutional power of the executive branch}

The most direct and visible effect of the institutional context described above is the preponderance of the executive branch in the legal output. Figure 1 reveals that the institutional continuity reflects directly on the pattern of legal production. As a consequence of the constitutional changes introduced by the military regime, the executive became the main source of the enacted legislative initiatives. Under the Constitution of 1946, the laws originating in bills proposed by the executive corresponded to $43 \%$ of the laws and this participation rose to $89 \%$ during the military period. After the enactment of the Constitution of 1988, the pattern set by the military regime is maintained: the executive introduced $85 \%$ of the bills enacted. The reduction witnessed in 1994 cannot be seen as the beginning of a reversal of this pattern. It was due to the small number of laws accompanied by supplementary credits, that in other years corresponded to about half of the executive laws passed (see Table 1). 


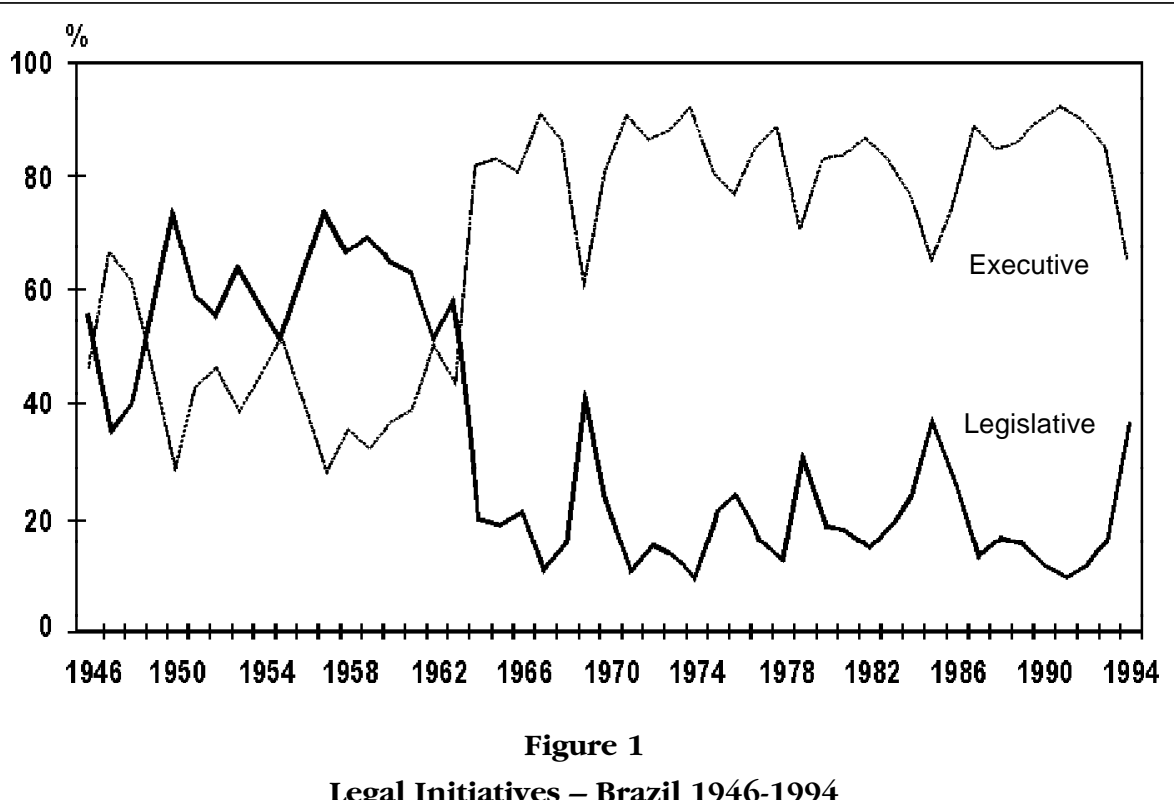

Sources: Pessanha (1991) and Banco de Dados Legislativos, CEBRAP.

Table 1

Legal Output: Laws Enacted (1989-1994)

\begin{tabular}{llllllll}
\hline YEAR & 1989 & 1990 & 1991 & 1992 & 1993 & 1994 & Total
\end{tabular}

National Congress

Exclusive initiative of the executive

\begin{tabular}{lrrrrrrr}
$\begin{array}{l}\text { Provisional } \\
\text { decrees (a) }\end{array}$ & 78 & 67 & 13 & 7 & 18 & 46 & 229 \\
$\begin{array}{l}\text { Budgetary } \\
\text { laws (b) }\end{array}$ & 102 & 51 & 118 & 132 & 105 & $8^{*}$ & 516 \\
$\begin{array}{l}\text { Subtotal } \\
\text { (a+b) }\end{array}$ & 180 & 118 & 131 & 139 & 123 & 54 & 745 \\
\hline
\end{tabular}

House of Representatives and Federal Senate

$\begin{array}{llllllll}\text { Exclusive } & 27 & 4 & 20 & 22 & 7 & 6 & 86\end{array}$

initiative of

the judiciary

power (c)

$\begin{array}{llllllll}\text { Executive } & 34 & 26 & 66 & 38 & 61 & 27 & 252\end{array}$

bills (d)

$\begin{array}{llllllll}\text { Legislative } & 38 & 18 & 19 & 22 & 34 & 45 & 176\end{array}$

bills (e)

$\begin{array}{llllllll}\text { Subtotal } & 99 & 48 & 105 & 82 & 102 & 78 & 514\end{array}$

\begin{tabular}{llllllll}
$(\mathrm{c}+\mathrm{d}+\mathrm{e})$ & & & & & & & \\
\hline Total & 279 & 166 & 236 & 221 & 225 & 132 & 1,259
\end{tabular}

* The small number of budgetary bills for this year is due to the fact that the budget was only voted on at the end of the year and supplementary credit requests were introduced through provisional decrees.

Sources: Prodasen and Banco de Dados Legislativos, CEBRAP.
Table 1 presents data that allow for a characterization of legislative output in the period after the 1988 Constitution. The first subtotal represents the laws in which the executive retains the constitutional right of exclusive initiative: provisional decrees and laws that refer to budget matters. The budgetary laws comprise the annual budget and laws concerning the granting of supplementary credits to the annual budget. These laws modify the previously voted budget through additional, special, and extraordinary transfers of resources from one budget item to another. The National Congress - the joint session of the two legislative houses - considers the provisional decrees and the budgetary laws. These laws are not sequentially examined by each of the legislative houses. Provisional decrees are examined by a joint committee (of the House and the Senate) formed especially for this purpose, and budget laws are examined by a joint budget committee (Comissão Mista de Orçamento). The laws that are processed sequentially in the House and the Senate are found in the lower part of the table. They are divided into three categories: those that are the exclusive initiative of the judiciary branch, and the legal initiatives 
of the executive and legislative branches. Part of the laws sponsored by the executive branch included here is also, constitutionally, in the sphere of its exclusive initiative. These deal with the creation of positions and functions in state companies, in public administration, in the indirect administration of public entities (public utilities); salary and hiring practices for civil service jobs; creation, structure and attributes of ministries and public administration organs, and the regulation of the size and modification of the Armed Forces troops.

Table 1 shows unequivocally the executive branch's impact on legislative production as a direct consequence of its institutional prerogatives. Laws originating as provisional decrees and bills concerning budgetary matters account for $60 \%$ of the total laws for the period. The executive also amply surpasses the legislature in cases where the legislative can also initiate bills. Excluding the 7\% of the laws originating from the judiciary branch thatare also due to their constitutional prerogative, the executive is responsible for the proposal of $85 \%$ of the laws enacted in the post-constitutional period.

The executive preponderance is directly due to its capacity to control the legislative agenda. The rules that guarantee exclusivity to the executive, endow it with instruments to control the legislative agenda, either directly by defining deliberation deadlines, or indirectly by placing it in a strategic position to prioritize certain measures. Moreover, the executive uses these institutional mechanisms strategically to obtain the approval of its projects. ${ }^{18}$

Congress has a constitutionally defined time limit for deliberation on provisional decrees (PD). However, once published, they carry force of law. It is the responsibility of the legislature to react within a period of 30 days. If the decrees are not considered within this period, they lose their validity. But the executive can reissue the decrees. Should Congress reject a PD, it must regulate the resulting consequences. Besides that, in practical terms the rejection of a PD requires a qualified majority. In more polemic cases the executive can resort to obstruction, followed by reissuing of the original decree. Therefore the cost of forming a majority falls on the opposition.

The data presented in Table 2 indicates that the executive has made ample use of its power to issue provisional decrees. The government sent an average of 10 provisional decrees per month to Congress between 1989-1993. Only 14 PDs were rejected, 230 were approved, half of them in the form in which they were originally sent by the president and the other half modified and transformed into conversion bills (CB). The rest were reissued, revoked or expired.

Table 2

Results of Provisional Decrees Issued (1989-1994)

\begin{tabular}{lrrrrrrr}
\hline & 1989 & 1990 & 1991 & 1992 & 1993 & 1994 & Total \\
\hline PD issued* & 103 & 163 & 11 & 10 & 96 & 405 & 788 \\
Approved & 78 & 69 & 11 & 7 & 19 & 46 & 230 \\
$\begin{array}{l}\text { No changes } \\
\text { (PD) }\end{array}$ & 45 & 26 & 1 & 2 & 4 & 35 & 113 \\
$\begin{array}{l}\text { Modified } \\
\text { (CB) }\end{array}$ & 33 & 43 & 10 & 5 & 15 & 11 & 117 \\
Defeated & 6 & 7 & 1 & - & - & - & 14 \\
\hline
\end{tabular}

*The difference between the sum of defeated and approved PDs in relation to those sent refers to PDs that expired, were revoked or reissued.

Sources: Prodasen and Banco de Dados Legislativos, CEBRAP.

Bills that refer to budgetary matters include the pluriannual plans (PPA), budgetary directives (LDO), the annual budget (LOU), and the granting of supplementary credits to budget laws in force at the time. Generally, additional credit bills begin to be introduced in the second semester of each year, after it has been established that receipts have exceeded the income estimated in the budget law. They constitute an integral part of the budgetary process as they prove or establish legal bases that authorize governmental spending for a good part of the year. Thus the majority of these requests are evaluated within a pre-determined calendar and government activities come to practically depend on the speed with which they are processed. When the end of the year approaches, pressure on the legislature increases, due to budgetary constraints.

These two factors - the importance of govemment actions that depend on the approval of 
resources and budgetary exercise deadlines put crucial resources in the hands of the executive branch, allowing it to not only prioritize bills but to enjoy high chances of approval of their bills. In fact, the margin the executive branch leaves for legislative maneuvering is small. Rejecting a credit request or even postponing the decision to discuss it can paralyze the government, and consequently, carry losses for the representatives themselves. It would fall upon them to justify why, for example, resources destined for hospital X or Y did not arrive and why the ill were not cared for.

Table 3 assembles data on the average processing time of ordinary laws sanctioned, according to type and initiator. The data demonstrate that the agenda power is institutionally guaranteed to the executive.

Table 3

Processing Time in National Congress

by Type of Law

Laws Enacted (1989-1994)

\begin{tabular}{|c|c|c|c|c|c|}
\hline & $\begin{array}{l}\text { Average } \\
\text { (in days) }\end{array}$ & $\begin{array}{l}\text { Standard } \\
\text { deviation }\end{array}$ & Min. & Max. & $\mathrm{N}$ \\
\hline \multicolumn{6}{|c|}{ National Congress (joint session) } \\
\hline $\begin{array}{l}\text { PDs } \\
\text { (not modified } \\
\text { by Congress) }\end{array}$ & 25 & 6.2 & 2 & 34 & 113 \\
\hline $\begin{array}{l}\text { PDs (modified } \\
\text { by Congress) }\end{array}$ & 11 & 7.6 & 1 & 41 & 117 \\
\hline Subtotal (PDs) & 18 & 9.8 & 1 & 41 & 230 \\
\hline Budgetary laws & 56 & 44.5 & 2 & 435 & $515^{*}$ \\
\hline \multicolumn{6}{|c|}{ House of Representatives and Federal Senate } \\
\hline $\begin{array}{l}\text { Judiciary } \\
\text { bills }\end{array}$ & 234 & 202.9 & 12 & 966 & 86 \\
\hline $\begin{array}{l}\text { Executive } \\
\text { bills }\end{array}$ & 412 & 579.8 & 1 & 2,668 & 252 \\
\hline $\begin{array}{l}\text { Legislative } \\
\text { bills }\end{array}$ & 1,094 & 1105.6 & 9 & 5,027 & 176 \\
\hline Subtotal & 616 & 843.6 & 1 & 5,027 & 514 \\
\hline Total & 278 & 608.7 & 1 & 5,027 & $1,258 *$ \\
\hline
\end{tabular}

* No information available: 1

Sources: Prodasen and Banco de Dados Legislativos, CEBRAP.

Provisional decrees, as would be expected, have the shortest processing time of all the laws approved in the period. The average processing time for provisional decrees is less than 30 days. ${ }^{19}$
Provisional decrees modified by Congress (CBs) have an average processing time that is shorter than decrees approved withoutalterations because the starting date refers to the date on which the project, already modified by Congress, begins to be considered. This period must be contained within the 30 days limit from the day the provisional decree is sent to Congress.

Congress also responds quickly to the executive's requests for supplementary credits. Budgetary laws complete their processing in an average of 56 days. The contrast with other laws couldn't be greater. The lower part of Table 3, referring to the average time of the laws that pass sequentially in the two houses, shows that the legislature takes about three times longer to approve laws introduced by the representatives than the laws proposed by the executive. ${ }^{20}$

The explanation for this delay is also institutional, although of a diverse nature from the one we have pointed out until now. There is a fundamental difference among the three branches of government with respect to the bills that each of them proposes for Congress' consideration. While the judiciary and the executive sponsor bills as institutional agents, the members of the legislature propose bills individually.

The sponsorship of bills by congressional members does not necessarily need to be individual: parties, committees, or even informal groups of deputies can also submit them. This, however, is not the reality in the Brazilian Congress. In general, bills tend to be presented individually. That is, bills introduced by the legislature are the fruit of a decentralized decision-making process. However, the selection process of propositions presented by congressional members is a collective task. The time required for this task is built into the general processing time of a legislative bill. In other words, the processing of a legislative bill is at the same time a process of evaluation and selection. Forbills presented by the executive and the judiciary branches, the selection is done elsewhere. The bill arrives at the Congress ready and in some cases already negotiated. Table 4 presents data on all the bills introduced according to the initiator. The data clearly illustrate the consequences of the absence 
of this process of selection to the legislative capacity to approve its own bills.

Table 4

Bills Presented to the House of Representatives by Initiator (1989-1994)

\begin{tabular}{lrrrrrr}
\hline Initiator & 1989 & 1990 & 1991 & 1992 & 1993 & 1994 \\
\hline Legislature & 3,025 & 1,489 & 2,335 & 1,141 & 940 & 524 \\
Executive & 74 & 57 & 116 & 116 & 143 & 72 \\
Judiciary & 21 & 16 & 24 & 24 & 47 & 24 \\
\hline
\end{tabular}

Source: Câmara dos Deputados.

The selection process of an enormous pile of bills put forward by representatives conspires against the legislative efficiency measured as the capacity to appreciate its own proposals. Internal selection significantly increases the evaluation time of the legislature's own proposals.

Table 5 allows us to explore another angle of the executive-legislative relation with respect to the process of law making. In this table we included all the bills that passed the initial selection process and were submitted to a floor vote in both legislative houses in the 1989-92 period. These bills are grouped in the following way. The first set refers to bills sanctioned as law. The second refers to bills that were approved by the House of Representatives, but were not yet decided on by the Federal Senate, as late as May 30, 1994, the date on which this data was collected. The thind set represents all the bills rejected by floor vote. The third column shows the distribution, by the initiator, of bills rejected in the House of Representatives, and the fourth column shows those that were rejected in the Senate.

The first point worth noting in Table 5 is the fact that, in general, the number of bills rejected by the floor is small. However, the contrast between bills sanctioned as law and those defeated could not be greater in terms of their initiator. The low proportion of executive bills defeated is notable. Congress rejects many more of its own bills in its floor decisions. Table 5 shows the relatively high number of bills approved in the House of Representatives that are blocked by the Senate. Bills waiting for the Senate's approval are for the most part - 88\% - sent on from the House of Repre-

sentatives. This data makes it very clear that the bills introduced by the executive receive special treatment within the legislative branch: they move faster and have a higher rate of approval.

Table 5

Bills Submitted to Floor Decision by Initiator (1989-1994)

Bills approved

in the $H R$

without
the Senate's

Laws decision by Represen-

Enacted 5/31/1994 tatives Senate

\begin{tabular}{lcccc} 
Initiator & $\%$ & $\%$ & $\%$ & $\%$ \\
\hline Legislature & 14 & 88 & 91 & 96 \\
& $(176)$ & $(317)$ & $(77)$ & $(81)$
\end{tabular}

Executive 79

(997)

Judiciary

7

(86)

Total

100

$(1,259)$
11

(41)

0,1

(2)

100

(360)
9

(8)

(3)

100

(85)
* Includes bills defeated up until December 1993.

Sources: Prodasen and Banco de Dados Legislativos, CEBRAP.

In this section, we discuss the constitutional norms that endow the executive with control over the legislative agenda. On its own, this is not enough to explain why the legislature approves executive bills, and why it does so with such speed. Factors linked to the internal organization of the legislative work contribute to the preponderance of the executive in the legislative process and in legal output.

\section{The internal organization of legislative work}

The internal organization of legislative work is, above all, marked by executive actions. The legislative finds itself in a position in which the executive is capable of controlling the content, time and rhythm of work inside the Congress.

The standing orders of the House of Representatives established a centralized decision-mak- 
ing format in keeping with the preponderant role played by executive. If, in constitutional terms, the mechanisms that guarantee the primacy of the executive in legislative functions were maintained, in terms of the internal organization of its main legislative house, the House of Representatives, the continuity can also be observed. The standing orders reserved, and the practice has reinforced, a crucial role in the conducting of the legislative process to a restricted group of representatives in the college of leaders.

The decentralized organization of the legislature presupposes the effective functioning of a system of permanent committees in two senses: first, in such a way that these may come to be the locus of specialized decisions which guarantees improvements in the quality of legislation, and second, in that the committees are an obligatory route for legislative propositions that will be submitted to the floor. ${ }^{21}$ In another paper we discuss the role of the committees as an instance of specialized legislative decision-making. Here we are going to discuss only the second aspect mentioned above. These two aspects, however, are inter-linked to the extent that the emptying of the committees as a mandatory route for the passage of legislative propositions reduces incentives for more effective participation in committees, reinforcing its role as a specialized instance of legislative deliberation.

According to the congressional rules, committees are an organ of a technical nature and the first deliberative instance for bills introduced to Congress. Thus, when a bill is considered under ordinary procedures, the House director's board sends the legislative propositions it receives to the committees for written review that are in turn submitted for voting in the committee. Formal approval of the review in the committee is necessary to transform a bill into a law. The rejection of a written review in the committee or the nondeliberation of a bill in the same legislature leads to the filing of the bill. Once the committee's review is approved, the bill is ready to be included in the day calendar, and following that, to be submitted for deliberation by the committee. Invoking the terminative power instituted by the 1988 Constitu- tion, the committee can approve the bills under its jurisdiction. This means the bills do not have to be submitted to a floor vote, unless recourse against a terminative decision is accepted.

The legislative process in the House of Representatives, however, does not observe this flow. It is much more centralized. The college of leaders influences the legislative process through the approval of request for urgency, which alters the ordinary flow of bills. The bills are discharged from the committees. Although foreseen as a recourse to be used extraordinarily, in matters of relevance and urgency, urgent processing has being used as the main route for the consideration of bills in the House of Representatives. The majority of bills transformed into law in the 1989-94 period was processed in a regime of urgency in the House. Of 514 laws, ${ }^{22} 282$ (or 55 percent) resulted from requests for urgency made by the legislature, out of which 203 were voted as extremely urgent.

Figure 2 shows the different routes followed by the bills transformed into laws; that is, the ones that ran through the complete procedure in Congress, passing through the two legislative houses and obtaining presidential sanction. The chartindicates the number of laws that completed each of these routes. The middle of the chart shows the regular flow of a bill that is approved by the House floor after being deliberated and approved by the committees. Of 514 laws sanctioned, only 29 percent (151 laws) follow this route. The upper part shows the trajectory of a bill approved by means of the "terminative power" of committees, dispensing floor evaluation. As can be seen, 81 laws, 16 percent of the total, were approved by the terminative procedure in the committees. Finally, the lower part of the chart shows the approval rates of laws passed with urgency. The vertical arrows indicate the number of laws and the stages of legislative process in which urgency for the corresponding bills was requested. As can be observed, 241 bills were processed with urgency before the committees responsible for evaluating them had a conclusive written review about them. In only 41 bills did the committees completely fulfill their deliberative role. 


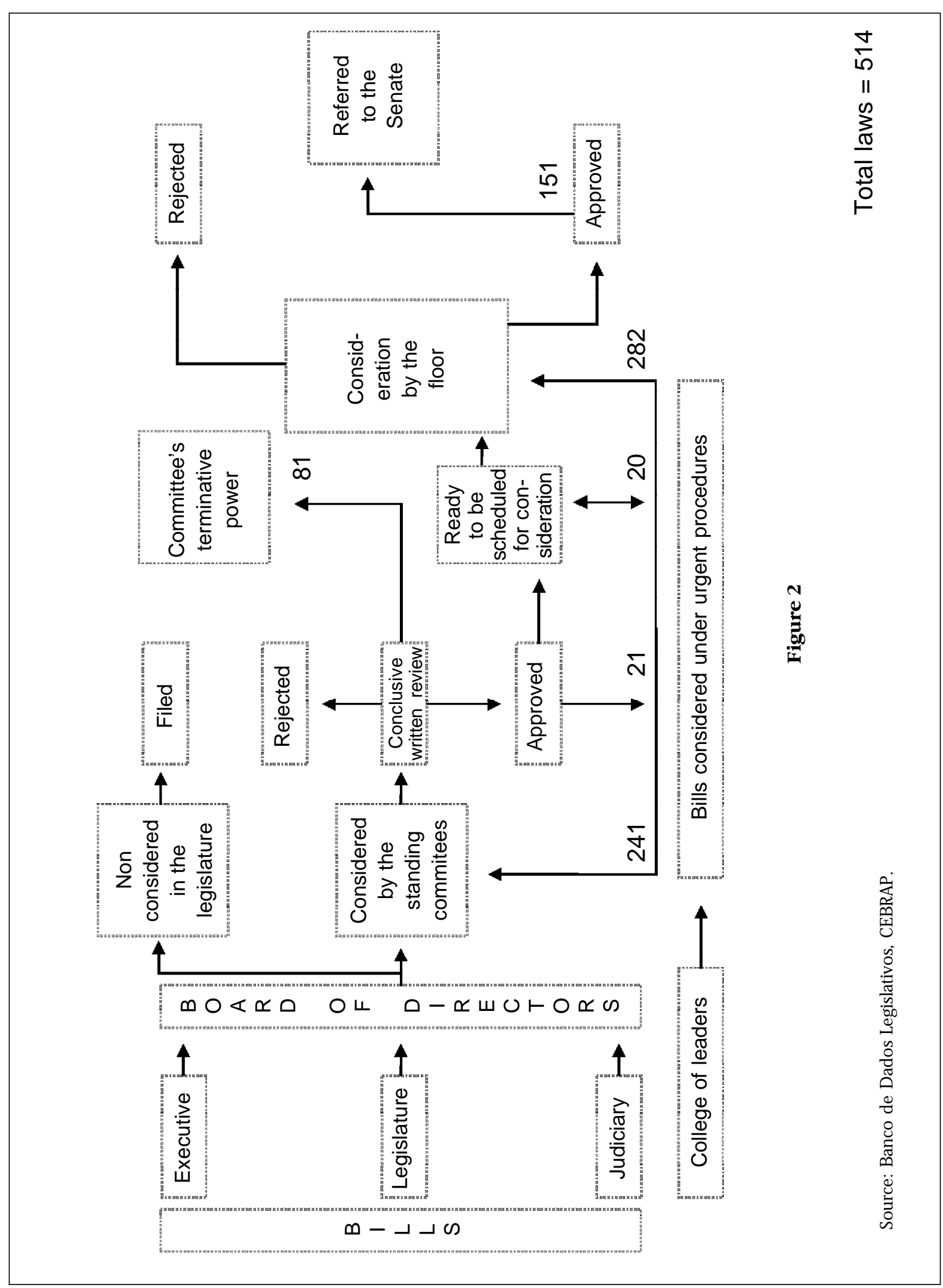


It is unnecessary to emphasize the effect of the urgent processing on the role of the committees in the legislative process and on its own consolidation. The standing orders, however, try to preserve the role of the committees in their assessment of bills under theirjunisdiction, even underurgent procedures. If the request for urgency occurs before the committee written review is published, and the committees feel unable to emit such a review in the session the urgent bill is included in the day calendar, the committee can requesta postponement of two legislative sessions in order to write the evaluation. At the end of the time granted, the floor can consider the bill even if the report is not ready. In the absence of the written review, the speaker nominates a representative (relator deplenário), who will give a verbal evaluation of the bill in the floor. This representative is not necessarily a member of the bill's original committee. In previous regulations one can see that this requirement was present. The consideration of a bill under urgent processing did not forfeit the need for a formal review, even if verbal, issued by the respective committee. Today the speaker tends to choose a representative from among the members of the committee that considered the bill and often this representative is the same who had been indicated to give the report on the bill in the committee. However, even if this is a general rule, it is not the committee that is being called to give its opinion. In this sense the practice of indicating a floor relator inevitably preempts the functioning of the committee as a collective decision-making body. ${ }^{23}$ This means that, in fact, committees do not have total control over the decision-making process of proposals under theirjurisdiction.

The average time elapsed between a bill's presentation date and approval of the request for urgency for the bills enacted reveals, in a more pressing manner, the impact that this special processing procedure has over the decision-making power of the committees. As is shown in Table 6, a considerable proportion of laws had the request for their consideration under urgent procedures approved in less than 15 days after their introduction to the House of Representatives. Many of these bills are approved in one day. This time period is notoriously brief for evaluation of a bill.
Table 6

Processing Time before Petition for Urgency Ordinary Laws Enacted (1989-1994)

\begin{tabular}{lrrr}
\hline Processing time & $N$ & $\%$ & \% cum. \\
\hline Less than 15 days & 117 & 41.5 & 41.5 \\
15 to 30 days & 29 & 10.3 & 51.8 \\
1 to 3 months & 52 & 18.4 & 70.2 \\
3 to 6 months & 23 & 8.2 & 78.4 \\
6 to 12 months & 22 & 7.8 & 86.2 \\
More than 1 year & 39 & 13.8 & 100.0 \\
Total & 282 & 100.0 & \\
\hline
\end{tabular}

Sources: Prodasen and Banco de Dados Legislativos, CEBRAP.

The data presented up to this point leave no doubt as to the impact the urgent processing has on the decision-making powers of the committees. As we have shown, committees do not play a significant role in defining the agenda or in exerting influence on the substance of the laws approved. ${ }^{24}$

The college of leaders, through the mechanism of urgent processing, is decisive for the proper functioning of the House and of the transformation into law of bills introduced there, which also implies a passage through the Senate and the president's sanction. This can be observed from the comparison of the procedures for the processing of all bills that were submitted for decision by the floor in the House. Here we return to the distinction made in Table 5, among three different sets of bills: those transformed into law; those that were approved by the Lower House but have not yet been submitted for approval by the Senate at the end of May 1994; and bills defeated by the floor of either one of the two legislative houses. Table 7 shows the different procedures - ordinary, committees' terminative decision and urgent - for the processing of the bills in each of these sets.

Table 7 shows that the laws approved in the House which completed their entire process in Congress, followed a path completely different from those that are waiting for a decision in the Senate. The laws sanctioned in the period, for the most part, passed through the committees that rarely use their terminative power, while the bills that are in the Senate go through committees and are approved, for the most part, by teminative decision, that is, they are not subject to floor vote. 
Table 7

Bills Submitted to Floor Decision by

Procedures for Consideration (1989-1994)

\begin{tabular}{|c|c|c|c|c|}
\hline \multirow[b]{2}{*}{ Bills } & \multicolumn{3}{|c|}{ Procedure } & \multirow[b]{2}{*}{ Total $(n)$} \\
\hline & Urgent & Terminative & Ordinary & \\
\hline Ordinary laws enacted (\%) & 55 & 16 & 29 & $514^{*}$ \\
\hline $\begin{array}{l}\text { Ordinary bills approved in the House without } \\
\text { decision in the Senate by } 5 / 30 / 1994(\%)\end{array}$ & 12 & 62,5 & 25,5 & 360 \\
\hline $\begin{array}{l}\text { Ordinary bills defeated in the House of } \\
\text { Representatives (\%) }\end{array}$ & 5 & & 95 & 84 \\
\hline $\begin{array}{l}\text { Ordinary bills approved in the House and } \\
\text { defeated in the Federal Senate (\%) }\end{array}$ & 7 & & 93 & 85 \\
\hline
\end{tabular}

* We have excluded the laws introduced as provisional decrees and the budgetary laws.

Sources: Prodasen and Banco de Dados Legislativos, CEBRAP.

These two sets of laws also differ with respect to their content. Table 8 compares the set of bills detailed above, according to their subject matter. The classification of the content of this legislation was made from the summaries of the bills. As such, inferences about their substantive meaning are limited and subject to further exploration. With this caveat, we consider that such summaries provide an adequate basis to classify the different areas of activity subject to legal regulation. We distinguish five areas: administrative, economic, social, political-institutional and last, with reference to an honors role. A great part of the laws understood as administrative are the sole concern of the executive branch or of the judiciary. They refer to: the creation and extinction of positions and public organs; definition of competency, composition and functioning of governmental organs; setting up of numbers of troops for the military or police force; establishment of payment dates and benefits for public workers. Also included in the category of administrative laws were the donation and alienation of real estate or state properties, debtamnesty, the establishment of limits between states of the federation, etc. The economic laws refer to salary, taxes and general regulation of the economic activities in the different areas - industrial, commencial, financial, etc. and etc. The social laws are understood as not only referring to social programs, stricto sensu, in areas such as health, education, social security, housing, labor, but also to a wide range of social activities such as the environment, the justice system, professions, civil rights, etc. The political-institutional laws regulate the organizations of the three branches of government, electoral systems and political parties. Under the label "honors" are those laws which name monuments and streets, establish holidays, national days, etc.

Congress, as we have said earlier, rejects only its own bills. Among the bills enacted there is a predominance of bills initiated by the executive. The bills that have not yet been deliberated on in the Senate or have been defeated, on the contrary, are almost all bills introduced by members of the legislature. It is also clear in Table 8, that there are two agendas in these different sets of bills: the "economic-administrative" agenda of the executive and the "social" agenda of Congress. The main instrument utilized by the executive in the implementation of its economic agenda has been provisional decrees: half of them are of an economic nature. Administrative bills are introduced as ordinary bills, also almost half of the laws resulting from the executive initiative. If we take into account the 516 laws referring to the requests for supplementary credit and budget matters, the economic-administrative agenda of the executive branch is even more impressive.

The "social" agenda of the legislative power includes bills that refer to the following aspects: regulation and extension of social rights and labor bills (there is a great number of bills altering or 
Table 8

Bills Submitted to Floor Decision by Area and Initiator (1989-1994)

\begin{tabular}{|c|c|c|c|c|c|c|c|}
\hline \multirow[b]{3}{*}{ Area } & \multicolumn{3}{|c|}{ Laws enacted } & \multicolumn{2}{|c|}{$\begin{array}{l}\text { Bills approved in the } \\
\text { HR without decision by FS }\end{array}$} & \multicolumn{2}{|c|}{$\begin{array}{c}\text { Bills defeated } \\
\text { in HR or FS }\end{array}$} \\
\hline & \multirow[t]{2}{*}{ Legisl. } & \multicolumn{2}{|c|}{ Exec. } & \multirow[t]{2}{*}{ Legisl. } & \multirow[t]{2}{*}{ Exec. } & \multirow[t]{2}{*}{ Legisl. } & \multirow[t]{2}{*}{ Exec } \\
\hline & & $\mathrm{PD}$ & Others & & & & \\
\hline Economic & 24 & 48 & 22 & 9 & 26 & 15 & 27 \\
\hline Administrative & 11 & 27 & 48 & 6 & 24 & 22 & 37 \\
\hline Social & 57 & 21 & 29 & 76 & 40 & 42 & 27 \\
\hline Pol.-institutional & 1 & 3,5 & 0,3 & 1 & - & 9 & - \\
\hline Honors & 7 & 0,5 & 0,6 & 3 & 8 & 12 & - \\
\hline Unidentified & - & - & 0,3 & 4 & 2 & - & 9 \\
\hline \multirow[t]{2}{*}{ Total } & 100 & 100 & 100 & 100 & 100 & 100 & 100 \\
\hline & $(176)$ & $(197) *$ & $(252)$ & (317) & (38) & (158) & (11) \\
\hline
\end{tabular}

* We excluded 32 budgetary laws that were sent as provisional decrees despite the constitutional prohibition in this sense. Sources: Prodasen and Banco de Dados Legislativos, CEBRAP.

adding articles to the labor code, the CLT, and regulating rights established by the 1988 Constitution); regulation and definition of civil rights and citizenship, consumer protection and safety; alterations of the civil and penal codes; regulation of professions, etc. It is not possible to make a substantive analysis of the content of these bills from their summaries, though themes of this nature predominate in both the bills sponsored by the legislature that are transformed into law and those awaiting the Senate's decision. It is worth noting that a great number of these bills do not manage to complete their processing - double the number of legislative bills that were sanctioned - and the differences in the procedures for their processing. The average processing time of these bills is still greater than those that were sanctioned: 1,390 days, compared with 1,094 . The contrast with the set of 516 bills enacted is impressive: 77.5 percent of these bills were being processed for more than two years. This only happens with 6 percent of the bills sanctioned as law. In other words, there is no doubt that the House has difficulty in assuring the processing of its own bills.

The executive agenda, on the other hand, is not only approved, but also has a more rapid processing. Urgency, as can be expected, is a powerful instrument of speeding up the processing of bills. The bills enacted took an average time of only 26 days after the approval of the request for urgency to reach the Senate. However, urgency is much more effective for executive bills. Before we address the different effects of urgency on the executive and on the legislative bills, it is necessary to examine the characteristics of the bills enacted that were processed urgently, because these reveal the low efficiency of the functioning of the Lower House.

The processing of bills under the urgent procedure is not only used for the most important matters that pass through the House. Contrary to what might be expected, it is through this mechanism that the college of leaders deals with a great part of the routine matters that is considered in the House. That is, it guarantees that the legislature will respond to the demands of the other two branches, in reference to their legislative needs, as constitutionally defined. We start this analysis considering the initiator of the enacted bills passed with urgency.

Note in Table 9 the fact that the processing of bills in regime of urgency is the rule for the bills the judiciary introduces. According to constitutional norms, only the judiciary itself can introduce bills that regulate its activities. Consequently, the functioning and expansion of this power depends on these laws. Anotherway to approach this question is to verify the distribution by subjects of the bills processed in regime of urgency, as shown in Table 10. 
Table 9

Ordinary Laws Considered under

Urgency Procedures in the

House of Representatives (1989-1994)

\begin{tabular}{lccc}
\hline Initiator & $\begin{array}{c}\text { Urgent } \\
\text { procedure }\end{array}$ & $\begin{array}{c}\text { Total } \\
\text { laws }\end{array}$ & $\begin{array}{c}\text { Laws } \\
\text { w/ }\end{array}$ \\
\hline Legislature & 75 & 176 & 43 \\
Executive & 134 & 252 & 53 \\
Judiciary & 73 & 86 & 85 \\
Total & 282 & $514^{*}$ & 55 \\
\hline
\end{tabular}

* We have excluded budgetary laws and the laws issued originally as provisional decrees.

Sources: Prodasen and Banco de Dados Legislativos, CEBRAP.

Table 10

Ordinary Laws Enacted by Area and Urgency (1989-1994)

\begin{tabular}{lccr}
\hline Area & $\begin{array}{c}\text { Urgent } \\
\text { procedure }\end{array}$ & $\begin{array}{c}\text { Ordinary } \\
\text { procedure }\end{array}$ & Total \\
\hline Economic & 57 & 40 & 97 \\
Administrative & 147 & 79 & 226 \\
Social & 69 & 103 & 172 \\
Pol.-institutional & - & 3 & 3 \\
Honors & 9 & 6 & 15 \\
Unidentified & - & 1 & 1 \\
Total & 282 & 232 & 514 \\
\hline
\end{tabular}

Sources: Prodasen and Banco de Dados Legislativos, CEBRAP.

The use of urgent procedure for administrative bills stands out: 65 percent of them were processed with urgency. The administrative area includes all the laws introduced by the judiciary and a considerable part of the bills introduced by the executive. As we see, the executive, by constitutional determination, also has an exclusive initiative in bills regulating the organization and functioning of the federal administration.

Everything indicates that the action of the college of leaders, through the requestfor urgency, functions as a guarantee that these bills will not only be voted on, but that they will be voted on in the necessary timeframe. Through an exceptional recourse, the college of leaders makes sure that the administrative demands of the executive and judicial powers are met. This shows that the House of Representatives does not manage to establish a regular routine through which bills dealing with non-controversial matters and day to day public administration can follow a regular legislative path. That is, the establishment of a consensual calendar mobilizes within the House of Representatives an organ that brings together the party leaders to perform the tasks required for routine public administration, in detriment of the negotiation functions more akin to its partisan nature.

In order to compare to other experiences of the organization of legislative work, let us take a look at what occurs in the case of the US House of Representatives. Non-controversial measures are organized in a "consensual calendar". The bills included under such a heading also enjoy privileged access to the floor, and are deliberated upon on predetermined days. This calendar is organized in an administrative form and is supervised by six "objectors", three members of each party, officially indicated by majority and minority leaders. The objector's task is to the deliberation on bills that: (1) involve expenditures above 1 million dollars; (2) promote changes in domestic and international policies and (3) involve substantive questions that may provoke debates in the floor. In this way, the agenda is free of consensual questions and committees and the floor can occupy themselves with the controversial questions, that is, with substantive issues.

In the 49th legislature (1991-1994), three proposals were presented which, combined, sought to reorganize the legislative work in the House: an abbreviated procedure for the evaluation of noncontroversial propositions, the definition of a working schedule of the legislative activities and the creation of a "triage" committee. ${ }^{25}$ The first consisted in the selection, by the speaker, of those bills that do not involve controversies and their vote in blocks. This comesponds to the formation of a consensual calendar in the US mode. The proposal for the previous definition of the House's agenda had the objective of making "efficient management of the legislative process" possible. According to the diagnosis of this committee, the lack of management of the House's work determined the fulfillment of a "bureaucratic and non-political schedule" in the processing of legislative propositions. In this way "the consideration of controversial matters is 
indefinitely postponed while the irrelevant propositions tend to prevail, filling up the agenda of the committees and the floor". The special committee proposed that the speaker, with the help of party leaders, would define a set of relevant themes and identify the propositions being processed on these themes, and encourage, whether through committees or individual congressional members, the presentation of bills on the same matters. In the end, this process would result in the definition of an agenda composed of bills of "national interest and relevance". The role of this group - in fact, the college of leaders itself ${ }^{26}$ - would then be to select and evaluate a substantive agenda of legislative bills.

Finally, the "triage" committee, according to the proposal of the modernization committee, should be composed of members appointed by the speaker. This committee's main task would be to decide whether the bills proposed by representatives meet constitutional and standing orders requirements. It would also decide about the "jurisdicity" of these bills. The concept of "jurisdicity", according to the recommendation of the committee, should remain without a definitive explanation as it "emerges from an exercise of prerogative, that would create wholesome jurisprudence regarding it" that would have the "function of inhibiting the proposition of bills contrary to the understanding of this committee". The committee stated clearly the main objective of its proposal: to inhibit the presentation of bills "sponsored in response to solicitations outside the House", which are understood as encompassing so-called "regional bills" and "category bills", in contrast to the "bills sponsored out of personal judgement and conviction" that should be stimulated. In the first two types of bills, the committee report says that the objective of the congressional members, rather than to see the bills processed, was instead the "mere communication to their constituencies, through the individual announcements of the material on the Hora do Brasil [the daily government radio program that broadcast governmental information]”. According to the committee's own estimates, these constitute the great majority of bills sponsored by congressional members. Given these arguments it is not surprising that the floor rejected the modernization committee's recommendation.

Of the three proposals for the organization of legislative work, only one considered the issue of the non-controversial proposals and tried to organize a sort of consensual calendar for block voting referred to these issues. The other two implied an excessive delegation of power and, consequently, an even greater centralization of the legislative process. Such a mandate is very difficult to obtain in any legislative body.

The college of leaders, in fact, through the mechanism of urgency, attempts to unencumber the administrative agenda of the House. As can be seen in Table 11, urgency is necessary for the executive and legislative bills to be approved rapidly. However, legislative bills dealing with administrative matters (which are a very small number of bills) are not different from the executive bills. This shows that the path to be followed in the organization of legislative work should be, primarily, addressed to the consensual agenda. In this way, the time and structure of the decisions in force would be liberated for deliberation on a substantive agenda. As in any other legislative assembly, if this agenda is to be confronted there is no other way than through the political debate and negotiation.

The actions of the college of leaders are not limited to the administrative agenda. In areas in which the legislative and the executive in fact compete for the initiative of the bill - those bills dealing with economic and social matters - the college of leaderalso performs a crucial role. In relation to these bills, there are sharp differences between the executive and the legislative branches. Urgent processing procedures have greater effect on executive bills. However, even executive bills that are not urgently processed pass more quickly through the House and have a shorter final processing time. In this case, the influence of the institutional factor mentioned in the previous section should be remembered, that is, the fact that the internal selection process of the bills initiated by the representatives is computed in terms of the general processing time, while the proposals of the executive and the judiciary arrive already prepared and often pre-negotiated. All these aspects can be observed in Table 11. 
Table 11

Average Processing Time By Origin, Urgency and Area Laws Enacted (1989-1994)

\begin{tabular}{lcccc}
\hline House of Representatives & \multicolumn{2}{c}{ (in days) } \\
\hline \multicolumn{3}{c}{ Legislature } & \multicolumn{2}{c}{ Executive } \\
Area & w/ & w/o & w/ & w/o \\
All areas & 390 & 844 & 125 & 473 \\
Administrative & 54 & 910 & 109 & 560 \\
Economic-social & 467 & 836 & 140 & 397 \\
\hline National Congress & urgency & urgency & urgency \\
\hline \multicolumn{5}{c}{ Legislature } \\
\multicolumn{4}{c}{ Executive } \\
Area & w/ & w/o & w/ & w/o \\
All areas & urgency & urgency & urgency & urgency \\
Administrative & 602 & 1,460 & 210 & 642 \\
Economic-social & 285 & 1,623 & 156 & 738 \\
\hline
\end{tabular}

Sources: Prodasen and Banco de Dados Legislativos, CEBRAP.

It is not to overstate to point out that the executive bills on economic and social matters whether processed urgently or ordinarily - pass much more rapidly through the House than those of the legislative. The same occurs in relation to complete processing, including its passage through the Senate and presidential sanction. Moreover: legislative bills passed with urgency take almost double the time to be approved in the House than do executive bills in ordinary processing procedures. This data leaves no doubt about the privileged treatment given to executive bills.

In summary, the executive defines the legislative agenda and determines the content of the legal output. Congress shows itself to be incapable of moving forward with its own agenda. The executive agenda follows an exceptional route, with urgent procedures, while the legislative bills follow the path of committees and terminative power. A great part of these proposals finds resistance in the Senate.

\section{Conclusion}

There is a strong, and in general little noted, institutional continuity between the authoritarian period and the present democratic period with respect to the rules that regulate the relations between the executive and legislative branches of the government. Contrary to what is normally affirmed, the legislative powers of the president their capacity to influence and direct legislative work - were not restricted by the new Constitution. They are infinitely superior to those available to the presidents of the 1946-64 period and therefore are not very distant from those available to the presidents of the military period.

The effects of this institutional framework are visible in the law making process and in the legal output. The analysis of the relative participation of the executive and the legislature in sponsoring the approved bills reveals that the promulgation of the new Constitution has not significantly altered the pattem of legal output. The strong preponderance of the executive as observed throughout the military regime has been maintained. The capacity to issue - and reissue - provisional decrees, the prerogative to request urgency for bills and the strategic advantages available in the consideration of the budget and supplementary credit bills guarantee the president the capacity to dictate how, when and what will be placed on the legislative agenda.

The House of Representatives is organized in a centralized form. The bills that come to be sanctioned depend, for the most part, on the actions of the college of leaders, who, through the institutional powers it holds, structures the legislative agenda and facilitates the legislative process, especially those proposals originating in the executive and judicial branches. The college of leaders operates through the approval of the request for urgency to process the bills that it wants to be voted on. This timetable is quite frequently used to approve administrative issues. That is to say that the House uses recourses reserved for extraordinary situations to deal with non-controversial matters.

The result of this practice is the emptying of the committees and of the floor itself. They both lose their main functions. Deliberation of the college of leaders precedes the deliberation in these loci of power. To summarize, the House of Representatives shows itself to be an inefficient organization. Moreover, the form in which the work is organized creates a vicious circle.

Expecting the pace of work to be slow, the college of leaders intervenes in the processing of bills and forces a rapid deliberation in the floor. 
Since this intervention is previously negotiated, the participation of the congressional members in the floor depends on the results of the negotiations between the leaders. In most cases it is just a matter of reconfirming previous agreements. The participation of members of Congress only occurs when all the possibilities of an agreement have been exhausted and the matter is submitted to a vote. In this form, the bulk of the legislative work is independent from the effective participation of congressional members, mining incentives for their participation. Given this form of organization of legislative work, it comes as no surprise that absenteeism so characterizes Congress.

Members of Congress are not unaware of such problems. Many proposals to alter the mechanics of the legislative process exist. As pointed out earlier, the proposals presented by the modernization committee reinforce rather than break this vicious circle. The determination of the agenda comes to be wholly controlled by a small group, and majority participation comes to be restricted to a discussion of bills already submitted to the selection process of this group.

Even though inefficientfrom an organizational standpoint, the way in which work is organized favors the executive. Availing themselves of a centralized group in order to negotiate, namely the college of leaders, the executive sees the minimization of uncertainties and difficulties associated with decentralized negotiation. The executive relates directly to the college of leaders, who also have an interest in strengthening theirinstitutional leadership by reducing the uncertainties of political conflict.

Evidences presented throughout the article shows that the legislature's behavior towards presidential initiatives is better characterized as cooperative rather than conflictive. From any angle of analysis, the presidential initiatives received special treatment. They were granted a greater number of urgent procedures, were processed more quickly and were, in the great majority, approved. Data shown reveal that the college of leaders performs a key role in creating the conditions for this cooperative behavior.

Considering all these evidences, one is forced to conclude that the Brazilian Congress does not constitute an obstacle to the govemmental action of the executive. The argument that Congress presents an insurmountable obstacle to presidential policies is not sustained in a reading of legal texts, and gathering of empirical evidence. On the legal side, the 1988 Constitution retains many of the legislative powers of the executive added to the 1946 Constitution by the military regime. ${ }^{27} \mathrm{On}$ the empirical side, we observe that the large majority of bills submitted to Congress by the executive are approved in a short space of time.

Empirical evidence does not support the view that the Presidency only sees its bills approved after extenuating and costly negotiations, with majorities formed on a case by case basis through individual bargaining. If this were so, the processing time of its bills would be much greater and the rate of approval would not be as high. If there is a crisis of governability, the charge should not fall on the Congress.

Certainly, an argument still remains: the legislature's cooperation with presidential bills so far presented does not guarantee the cooperation for all and any presidential initiative. Put in another way: the president does not send bills he anticipates will have difficulty in passing. Knowing he may be defeated and acting in a strategic manner, the president keeps quiet.

Before anything else, we should acknowledge that the data presented throughout this article do not allow a complete response to this objection. Case studies on bills of great importance to the executive can offer an empirical basis that allows for a definitive evaluation of the president's goveming capability. ${ }^{28}$ However, it seems difficult to extend the argument much further than this. There are limits on the possible presidential initiatives available for study. We have demonstrated throughout this text that the president draws on numerous strategic advantages thatallow him to control the decision-making agenda within the legislative process. These advantages can be applied to two meanings that are normally attributed to the word agenda: in the sense of defining the substantive themes to be deliberated upon, and in the sense of determining the steps and sequence of procedures that must be followed throughout the decision-making process. 
The president can count on still another strategic advantage that has not been discussed in this text: to appeal directly to public opinion, utilizing his privileged access to the media. Given these advantages, for what reason would the executive not submit its bills to Congress? When it has a bill, why does it leave it in the drawer? Why doesn't it put it on the table?Wouldn't it be more appropriate to transfer the cost of rejection to Congress?29

How does the government get to find out about its imminent defeat? Or previous experiences reveal when Congress blocks this or that type of bill, or the negotiation process about that initiative has already begun and the members of Congress have let the president know that chances of approval are low. Data presented in the previous section reveal that past experience would hardly deter executive initiatives.

With this the set of initiatives for analysis is considerably reduced. The potential agenda can be ignored. The question, then, can be treated empirically. ${ }^{30}$ Only bills actually submitted for the evaluation of Congress deserve to be objects of analysis, whether effectively deliberated and defeated, or sent and then withdrawn by the presidentafternegotiations.

Evidence presented throughout this textshows that party fragmentation and the fact that the president does not rely on the support of a solid majority do not impede executive initiatives from being approved. The onus of proof changes hands. Party fragmentation does not necessarily lead to the paralyzation of Congress. If the presidential base of support is unstable, if veto coalitions prevail, and if coalitions follow state or local rather than party loyalties, are all points open to empirical investigation. ${ }^{31}$

Given the existing legal framework, there are strategic advantages that the executive branch can rely on to neutralize difficulties due to the existing party structure. In reality, this was the intention of the constitutional delegates in deciding to maintain the executive legislative prerogatives.

Continuity between the legal structure of the authoritarian period and that created by the new Constitution were noted throughout the constitutional delegates' work. However, contrary to what one would expect, this did not provoke significant divisions between the constitutional delegates: in fact, its adoption was close to consensual. Concerning the legislative powers of the president, there were no great gaps between the rightand left that were characteristic of constitutional work.

The adoption of provisional decrees illustrates the point made. ${ }^{32}$ Its inclusion in the Constitution preceded the vote on the system of government. The continuity between the provisional decree and the decree-law was noted in the discussions at the floor. This was the main argument presented by the delegates who proposed its removal from the constitutional text. ${ }^{33}$ The defense of the provisional decree was made, basically, from its insertion into the interior of a parliamentary system of government. And therefore, its defenders argued, the continuity thesis does not apply. Above all, because, according to this argument, the dependence of the prime minister in relation to the majority guaranteed a qualitatively diverse use of the provisional decree. ${ }^{34}$ The decision was taken to the vote and an overwhelming majority maintained the provisional decree. There were 275 votes in favor and only 78 against, a clear index that the majority of the constitutional delegates had no intention of retuming to the pre-1964 status quo. Once the change to a parliamentary system was defeated, the provisional decree was maintained, without having been the object of a new vote. ${ }^{35}$

The current negative evaluation of the legislature and the fear that Congress could become an obstacle to governability has heavily influenced the institutional choice made by constitutional delegates. The institutional interpretations of the 1964 crisis agree almost unanimously that at its root is executive/legislative conflict. There is no doubt about this point: the constitutional delegates sought to avoid these "obstacles" to effective governmental action. The parliamentary option can be taken as a manifestation of one of the most radical attempts to solve this problem. The experience during the Constituent Assembly contributed to reinforce this suspicion with relation to the legislature's capacity to overcome its own wounds.

The fact is that when they defined the institutional framework that regulates executive-legislative relations, members of Congress wanted to avoid obstructions in the governmental process due 
to the poor functioning or bad quality of the legislative process. To each and every possibility that the legislative come to constitute a blockade to executive action, the latter is given an escape valve that allows it to circumvent the legislature. In this sense, nothing is more significant than the permission contained in the $\mathrm{LDO}$ to which reference has already been made: in the event that the legislature does not approve the budget, the executive can have $1 / 12$ per month of the submitted budget. The legislative graciously gives up its bargaining power.

The legislature does not constitute an obstacle to the executive's govemmental action. This possibility was and is being removed by the parliamentary members themselves. Of course, this is not the same as saying that the legislative does not present problems, or performs its functions to its heart content. On the contrary, the effective legislative contribution to the govemmental process is small.

The chances of altering this picture are small. The expectation that, left to chance, the legislative process will be necessarily slow and fail justifies the ample legislative powers the executive and the college of leaders has been given. Yet these ample powers reinforce the problem they seek to avoid. The legislative initiative and the capacity to control the decision-making agenda are in the hands of the executive and the college of leaders. The bulk of the legislative work is effectively done without the contribution of the majority of Congress members. There is then, no incentive for theirparticipation. Neither do the decision-making instances in which this participation could be more effective, that is, the committees, become institutionalized. The circle closes. Expectations are fulfilled and justify the necessity for centralization and delegation of legislative powers to the Presidency.

\section{NOTES}

1 In a comparative study of presidential regimes in Latin America, Shugart and Carey (1991) note some of the effects of the president's legislative powers on the legislature and the political system.

2 Krehbiel (1991) is the most important reference on the analytical approach that focuses on the effects of the legislative organization, that is, the allocation of rights and resources to Congress members, on political outcomes.
3 See Pimenta da Veiga's speech defending the amendment (Diário da Assembléia Nacional Constituinte, 3.18.1988). Delegate Bernardo Cabral, in his report opposing the amendment, argued that it was not a constitutional matter. Cabral was defeated by 334 to 64 votes.

4 The 5th paragraph of Article 166 allows the president to modify the budget message sent as long as the voting for the same has not begun. In the last five years, three budgetary bills a year, on average, have been sent to Congress. For this reason, the budgetary bill relating to 1994 was only voted on in December of the same year. The opportunities for executive strategic behavior are numerous. Once more, we have an institution inherited from the authoritarian period and not present in the 1946 Constitution.

5 It is noteworthy that José Serra elaborated the first proposal for the LDO. Antonio Sérgio Rocha has enlightened us about this and several other issues regarding budgetary practices.

6 On this point, see Cebrap (1994).

7 The reinterpretation of the internal regulation of the Constitutional Assembly (Regimento Interno da Constituinte) obtained by the center-right (Centrão), practically returned the delegates' work to its starting point. Above all, it removed the Systematization Committee Ante-Project (Ante-Projeto da Comissão de Sistematização) from the condition of status quo. In this condition the text could only be modified if the proposed amendment obtained majority approval. The Centrists, through the institution of the separate voting, assured that each one of the articles listed in the Ante-Project depended on the majority's explicit approval. See Cebrap (1994).

8 The leadership selected the amendments to be submitted to a vote, combined the text of existing amendments and established agreements that allowed them to overcome impasses that emerged.

9 Paes de Andrade spelled out the criteria established in accordance with the party leaders to conduct the voting and immediately after that he closed the discussion on the subject ( $D C N, 4.28 .1989$, p. 2.820).

10 Not without some dispute. On one hand, the members of House board of directors did not want the institutionalization of the college of leaders while, on the other hand, small and medium parties sought to guarantee that the deliberations of this college would occur through consensus. Both sides were defeated by an alliance among PFL, PMDB and PSDB.

11 Party leaders who participate in legislative coalitions (blocos parlamentares) and the government leader have the right to a voice, but not a vote. Only parties with more than 6 representatives in the House have a seat in this college.

12 Note that this does not mean the permanence of the leadership vote. In the Lower House, the leadership vote was abolished, although it remained in the Senate and the National Congress (when both legislative houses meet in joint session). In the latter case this occurs because Senate regulations have precedence over the House of Representatives. 
13 Some matters, due to their nature, are processed with extreme urgency, as happens with such matters as declarations of war and peace.

14 This means that the matter is taken from the committee it was sent to and is discussed directly in the floor. After all possible recourses have been considered, and after the approval of the petition for urgency, the insertion of the issue into the day calendar can be postponed for a maximum of two sessions.

15 In accordance with Article 154 of the standing orders, the petition for urgency will be submitted for deliberation in the floor when it is presented by: (a) $2 / 3$ of the members of the House director's board; (b) $1 / 3$ of the members of the House of Representatives or leaders who represent this number; and (c) 2/3 of the members of the responsible committee. In this case the plenary session decides by plurality. As far as extremely urgent matters go, Article 155 establishes that the requirement must be submitted by "absolute majority of the House of Representatives or the leaders who represent this number and approved by the absolute majority of the members of the House of Representatives." (our italics).

16 In fact, there is an informal agreement between leaders so that urgent petitions, when underwritten by party leaders, come to be the object of deliberation in the college of leaders. See $D C N, 3.25 .1992$, p. 4.797, for a discussion during a plenary session about how such recognition is made.

17 With respect to the legislative agenda, the college of leaders can propose the convocation (which otherwise can only be made through deliberation by the floor) of extraordinary periods or sessions, designated for the sole purpose of voting on matters for which the convocation was made, and during which time ordinary sessions and the work of committees is suspended.

18 For a discussion of the power of the agenda and of proposition see Fiorina and Shepsle (1989); McKelvey (1976); Ordershook and Schwartz (1987), and Baron and Ferejohn (1989).

19 The procedural processing time registered was the date the law was sanctioned, and for this reason some bills exceed the 30 days defined constitutionally. That is, the provisional decree was approved within the stipulated time but took a few days to be enacted.

20 The short processing time of ordinary judiciary laws is due to the fact that they refer to matters of internal organization of the judiciary itself.

21 Regarding parliamentary committees central to congressional organization see Fenno (1971 and 1973); Krehbiel (1987a, 1987b and 1990); Rhode and Shepsle (1987) and Shepsle (1987a and 1987b).

22 The analysis from here on refers to this set of 514 bills that were processed in the two legislative houses.

23 In truth, committees in Brazil function as collective organs only in decisive instances and function very little as a locus of elaboration and improvement of bills presented. This role falls to the bill spokesperson, and constitutes an individual task.
24 Regarding the role of the committees in the selection of the enormous pile of individually sponsored bills, see Figueiredo and Limongi (1994) and Limongi and Figueiredo (1993).

25 These proposals are part of a set of 13 resolutions presented by the Modernization Committee that functioned during the months of April and May, 1991. The coordinator of the committee was Miro Teixeira and the relator was Nelson Jobim. Only two resolutions were approved: one that changed the role of the Comissão de Constituição e Justiça e Redação in the consideration of the bills submitted to the standing committees and another that altered the organization of the legislative sessions.

26 It is interesting to observe that one of proposals suggests the extinction of the college of leaders.

27 It is usually stated that the presidential system was added at the last minute to a Constitution designed to establish the parliamentary system of government, where we have an extremely strong Congress and an impotent Presidency. Such a formulation does not stand up to a simple reading of the 1988 Constitution.

28 Commentaries of Vilmar Faria forced us to clarify this point.

29 The president has ways to transfer the costs to Congress and he in fact does so. One example is the surprise senator Mario Covas expressed before the executive proposal of establishing an emergency fund (Fundo Social de Emergência). According to Dimenstein and Souza (1994, p. 119) he declared: 'You're kidding. They want to raise taxes. They want to take money away from governors and mayors. They're not giving anything in return, no immediate benefits [...] [the stabilization] plan doesn't freeze prices. And you expect this to be passed by Congress? Not even in dream [...]".

30 If we are willing to assume that the president behaves strategically in not turning public bills that he considers will not be passed, we are forced to treat as equally strategic his statements that his bills do not have a chance of passing successfully in Congress.

31 We are currently gathering evidences that will be the subject of analysis in another text. The analysis of the roll call votes, for instance, reveals a pattern of coalitions that are much more stable than expected. See Limongi and Figueiredo (1995).

32 This discussion benefits from the reconstitution and analysis found in Power (1994).

33 The amendment to suppress the provisional decree was presented by Adylson Motta (PDS-RS) and Michel Temer (PMDB-SP).

34 That is, it was argued that the provisional decree would be an exceptional recourse and that the continuity of the government would rest on its approval. As can be seen by a convoluted rationale, the defeat of the provisional decree was compared to a vote of confidence. There is nothing whatsoever in the text of the Constitution on any relation between the approval of the provisional decree and the continuity of the government. The de- 
fense of the provisional decree was made by constitutional delegates Pimenta da Veiga (PMDB-MG) and Nelson Jobim (PMDB-RS), using two other arguments: that a provisional decrees has a place in democratic regimes, as proved by their presence in the Italian Constitution, and that the complexities posed by the modern governmental process would require that the executive depend on extraordinary recourses of this order.

35 As to the presidential request for urgency, article 64 of the Constitution, no amendment intended to alter it was voted on. The House standing orders allow the president to request urgency at any time.

\section{REFERENCES}

ARON, David P. and FEREJOHN, John A. (1989), "The Power to Propose", in P.C. Ordershook (ed.), Models of Strategic Choice in Politics, Ann Arbor, University of Michigan Press.

BRIGADÃO, Clovis. (1973), Poder e Legislatura no Brasil: Análise Política da Produção Legal de 1959 a 1966. Rio de Janeiro, Iuperj.

CEBRAP. (1994), "O Desafio do Congresso Nacional: Mudanças Internas e Consolidação Institucional". Cadernos de Pesquisa, CEBRAP/Mellon Foundation, 3.

DEVESCOVI, Regina. (1995), "A Câmara dos Deputados e o Processo Decisório - Um Estudo de Caso sobre a Comissão de Seguridade Social e Família". Final report, research project "Terra Incógnita: Funcionamento e as Perspectivas do Congresso Nacional", vol. II, CEBRAP.

DIMENSTEIN, Gilberto and SOUZA, Josias de. (1994), A História Real: Trama de uma Sucessão. São Paulo, Ática.

FENNO, Richard F. (1971), "The House Appropriations Committee as a Political System: The Problem of Integration", in Herbert Hirsch and M. Donald Hancock, Comparative Legislative Systems, New York, The Free Press.

. (1973), Congressmen in Committees. Boston, Little Brown.

FIGUEIREDO, Argelina and LMONGI, Fernando. (1994), "O Processo Legislativo e a Produção Legal no Congresso Pós-Constituinte". Novos Estudos, CEBRAP, 38.

FIORINA, Morris P. and SHEPSLE, Kenneth. (1989), "Formal Theories of Leadership: Agents, Agenda Setters, and Entrepreneurs", in B.D. Jones (ed.), Leadership and Politics: New Perspective in Political Science, Lawrence, University Press of Kansas.
KREHBIEL, Keith. (1987a), "Sophisticated Committees and Structure-Induced Equilibria in Congress", in Matthew McCubbins and Terry Sullivan (eds.), Congress, Structure and Policy, New York, Cambridge University Press.

(1987b), "Why are Congressional Committees Powerful?'. American Political Science Review, 81.

. (1991), Information and Legislative Organization. Ann Arbor, The University of Michigan Press.

LIMONGI, Fernando and FIGUEIREDO, Argelina. (1993), "O Processo Legislativo na Câmara dos Deputados". Working paper, research project "Terra Incógnita: O Funcionamento e as Perspectivas do Congresso Nacional", CEBRAP.

. (1995), "Partidos na Câmara dos Deputados - 1989-1994". São Paulo, manuscript.

McKELVEY, Richard D. (1976), "Intransitivities in Multidimensional Voting Models and Some Implications for Agenda Control". Journal of Economic Theory, 19.

ORDERSHOOK, Peter and SCHWARZ, Thomas. (1987), "Agendas and the Control of Political Outcomes". American Political Science Review, 81.

PESSANHA, Charles. (1991), "O Poder Executivo e a Produção Legislativa no Brasil: 1946-1988". Paper presented at the XV Encontro Anual da Anpocs, Caxambu, MG, October.

POWER, Timothy J. (1994), "The Pen is Mightier than the Congress: Presidential Decree Power in Brazil". Paper presented at the XVIII International Congress of the Latin American Studies Association, Atlanta, EUA.

RHODE, David A. and SHEPSLE, Kenneth A. (1987), "Democratic Committee Assignment in the House of Representatives: Strategic Aspects of a Social Choice Process", in Matthew McCubbins and Terry Sullivan (eds.), Congress, Structure and Policy, New York, Cambridge University Press.

SHUGART, Matthew S. and CAREY John M. (1992), Presidents and Assembies: Constitutional Design and Electoral Dynamics. New York, Cambridge University Press.

SHEPSLE, Kenneth A. (1987a), "The Institutional Foundation of Committee Power". American Political Science Review, 81.

. (1987b), "Why are Congressional Committees so Powerful?'. American Political Science Review, 81. 